\title{
Hydraulic characterization from porous aquifers of the Brazilian Federal District
}

\author{
Caracterização hidráulica dos aquíferos porosos do Distrito Federal
}

Tatiana Diniz Gonçalves ${ }^{1 *}$, Christoph Lohe ${ }^{2}$, José Elói Guimarães Campos ${ }^{1}$

\begin{abstract}
Hydraulic conductivity $(\mathrm{K})$ in unsaturated soil is a key input parameter for modeling subsurface water and solute movements. $\mathrm{K}$-values are also important to better define the potential of aquifers and to optimize water resources management activities. Since K-values are usually not readily available, different techniques are applied to estimate them. This study aimed to estimate unsaturated K-values from porous aquifers found in the Federal District of Brazil. Infiltration tests were conducted in different soil types using the open-end-hole approach and the permeability test using shallow boreholes with specific depths, as reported by Heitfeld in 1979. Soil structure was taken into consideration in such estimations. In order to consider important soil properties such as soil texture and bulk density, K-values were also estimated by means of pedotransfer functions (PTFs). Soil texture was determined in the laboratory and used as input parameter for PTFs. Results from open-end-hole method and permeability test compared to those obtained from pedotransfer functions. K-values from four different shallow porous aquifers systems encountered in the Federal District varied from $10^{-8} \mathrm{~ms}^{-1}$ to $10^{-6} \mathrm{~ms}^{-1}$. Highest K-values were found in Oxisols while the lowest rates were found in Inceptisols. Decreasing conductivity trend was found with increasing depth due to the increase of loamy soils. Variations in the rate of hydraulic conductivity indicated heterogeneity of porous aquifers due to differences in textural and structural characteristics of the soils.
\end{abstract}

KEYWORDS: unsaturated hydraulic conductivity; open-end-hole; pedotransfer functions.

\begin{abstract}
RESUMO: A condutividade hidráulica (K) em meios não saturados é um parâmetro essencial para modelar fluxos de água e solutos no subsolo. Os valores de $K$ são também importantes para estimar o potencial dos aquiferos e otimizar a gestão de recursos hídricos. Tais valores geralmente não estão disponiveis e diferentes técnicas são aplicadas para obtê-los. O objetivo deste estudo foi estimar valores de $\mathrm{K}$ em meios porosos náo saturados na regiäo do Distrito Federal (DF). Foram realizados testes de infiltração em diferentes tipos de solo, utilizando o método open-end-hole, e ensaios de permeabilidade, em poços rasos com profundidades especificas, como descritos por Heitfeld (1979). Em tais estimativas a estrutura dos solos foi considerada. Valores de K também foram estimados por meio de funçôes de pedotransferência (PTFs). A textura dos solos foi determinada em laboratório e usada como parâmetro de entrada para o cálculo das PTFs. Os resultados do método open-end-hole e dos ensaios de permeabilidade foram comparados com aqueles obtidos pelas PTFs. Valores de $K$ de diferentes sistemas aquiferos rasos encontrados no DF variaram de $10^{-8} \mathrm{~ms}^{-1}$ a $10^{-6} \mathrm{~ms}^{-1}$. Os Latossolos apresentaram altos valores de $K$, enquanto que nos Cambissolos foram encontrados baixos valores. Uma tendência decrescente de condutividade foi observada com o aumento da profundidade, devido ao incremento de argila dos solos. As variaçóes dos valores de K indicaram a heterogeneidade dos aquiferos porosos devido, principalmente, a diferença das características estruturais e texturais dos solos.
\end{abstract}

PALAVRAS-CHAVE: condutividade hidráulica não saturada; open-end-hole; funçôes de pedotransferência.

1'Institute of Geosciences, Universidade de Brasília - UnB, Brasília (DF), Brazil. E-mails: tatianadinizgoncalves@gmail.com; eloi@unb.br ${ }^{2}$ Federal Institute for Geosciences and Natural Resources - Hanover, Germany. E-mail: Christoph.Lohe@bgr.de

*Corresponding author

Manuscript ID: 30219. Received: 12/30/2014. Approved: 05/12/2015. 


\section{INTRODUCTION}

Groundwater demand has grown significantly in the Federal District of Brazil in the past decades. According to the 2010 demographic census carried out by IBGE (Brazilian Institute of Geography and Statistics), 2.5 million inhabitants were living in the central Federal District by the year 2012, far beyond the originally planned 600,000 people for the year 2000. The study developed by Donald Belcher \& Associates in 1950, known as "Belcher Report" (CODEPLAN 1995), pointed out that the water resources in this region were environmentally fragile because of the dominance of high plateaus and the presence of important headwaters, small streams and rivers.

Nowadays, the basic services of water and energy supply, and wastewater treatment in the Federal District are insufficient to meet the demand of a growing population. Water supply in Brasilia (capital of Brazil) and its surrounding satellite cities is mainly dependent on two reservoirs (Santa Maria and Descoberto), some small streams, and groundwater. Major groundwater demand comes from more than 500 urbanizationsbuilt after 1990 (SEDUH 2006). Most of these residential communities are located in high plateaus and thick soils, which play an important role in recharging the aquifers. Urban occupation often seals surface soils, making rainfall infiltration more restricted. Consequently, there is a decrease in the groundwater and surface water availability. Residential communitiesoften establish their own water supply projects, based solely on their needs.

Such situation has motivated researchers to improve the knowledge of hydraulic conditions of local aquifers, which is necessary in order to better control and manage the groundwater utilization by local inhabitants or water suppliers. Campos and Freitas-Silva (1998), Souza (2001), Lousada and Campos (2005), Almeida et al. (2006) and Fiori et al.(2010), among others, classified aquifers based mainly on unsaturated hydraulic conductivity $(\mathrm{K})$, although the results are still incipient because of limited data concerning the potential and exploitation of the analyzed aquifers.

Estimating K-values from the Federal District shallow aquifers is important, because they are key parameters for the differentiation of aquifer bodies and their yield. Hydraulic tests such as infiltration tests support the delineation of different groundwater systems. These shallow aquifers play a crucial rolein recharging deeper aquifers, regulating stream flows, and contaminant flows, among other controls. Until now, there is no long-term monitoring system to create a consistent database necessary for the correct management of these aquifers.
$\mathrm{K}$-values from soils and saprolites can be measured by direct field methods or by indirect methods that estimate infiltration potential through other parameters. Most of the studies developed in the region used direct methods such as the double ring and open-end-hole. Field direct methods are time-consuming and expensive. As an alternative, pedotransfer functions (PTFs) are often used to estimate K-values indirectly, based on soil attributes such as texture, morphological structure, organic matter content and density (Bouma \& Van Lanen 1987). These methods were developed for soils from temperate regions. Therefore, adequation for tropical soils, mainly Oxisols (the most extensive soil type from tropics), is necessary.

The K-values showed in this study refer to vertical hydraulic conductivity in a specific depth. As the soil can be considered homogeneous in each horizon, it can be treated as an isotropic hydrogeologic medium, so that the vertical and horizontal hydraulic conductivity may be seen as the same order of magnitude. The estimated hydraulic conductivities are related to the unsaturated zone of the aquifers, since the in situ infiltration tests were developed up to $200 \mathrm{~cm}$ and the soil samples were collected in the shallow horizons.

Specific PTFs for tropical soils were proposed by Van den Berg et al. (1997), Tomasella et al. (2000, 2003), Hodnett and Tomasella (2002), Oliveira et al. (2002) and Benites et al. (2007). They developed PTFs based on multiple linear regression equations and artificial neural networks to determine the parameters specified in the Brooks-Corey (1964) and van Genuchten (1980) equations, or to estimate parameters related to water retention and hydraulic conductivity. This study aims to obtain unsaturated K-values from Federal District's shallow aquifers in order to contribute to the sustainable management of the water resources of this region.

\section{STUDY AREA}

The Federal District of Brazil is located in the Brazilian central plateau and covers an area of $5.789 \mathrm{~km}^{2}$. It includes three of the most important Latin American basins (Paraná, São Francisco and Araguaia-Tocantins) (Fig. 1). Streams are composed by small rivers. Aquifer recharge occurs dominantly in areas covered by natural vegetation, in thick soils and gentle slopes.

The potential of shallow aquifers depends among other features on relief, parental rock, climate and biological actions. Campos and Freitas-Silva (1998) classified them as porous aquifers if they occur in soils, weathered rocks and alluvium materials. Soils and saprolites correspond to 
unconsolidated materials with large horizontal and vertical extensions, ranging from a few meters to up to $80 \mathrm{~m}$ in thickness (average: $15-25 \mathrm{~m}$ ). They also point out that these systems are isotropic and heterogeneous.

The Brazilian Corporation of Agricultural Research (Embrapa 1978) produced a soil distribution map of the area. Different soil types show distinct conditions of infiltration and recharge because infiltration is controlled by thickness, textural and morphological structures, conductivity, vegetation, humidity, and slope. Textural and morphological structures are the main parameters to determine the dynamic processes in unsaturated zones of this environment.

The most representative soils of the region are Red Oxisols, Red-Yellow Oxisols, and Inceptisols (Embrapa 2006), which cover about $85 \%$ of the study area. Alfisols, Mollisols, Histosols and Entisols are also found in the study site. Oxisols present the best conditions for infiltration and recharge, which are frequently associated to savannas and occurring in flat to gentle topography. They occupy around $55 \%$ of the total area, show average thickness of $25 \mathrm{~m}$, and present sandy to clayey texture and a highly stable microstructure. Inceptisols have a smaller infiltration capacity. Inceptisols cover about $30 \%$ of the area and occur in hilly topography. They are typically thin, show sandy to loamy textures and blocky to granular structures. Grasslands are the most common vegetation cover. Other soil classes occur in small areas and are grouped in:

- Alfisols and Mollisols;

- Fluvic Entisols;

- Histosols; and

- Sandy Entisols.

The first group shows medium K-values with clayey texture, occurs in gentle reliefs and is strongly structured. The second group is represented by thin soils near streams and in gentle reliefs, and shows often loamy to clayey textures. Histosols have the lowest K-values and are related to wetlands. Sandy Entisols are composed essentially by quartz, derived from the weathering of quartzite.

The mineralogy of the soil layers is mainly controlled by the lithology of parent rocks of the Paranoá, Canastra, Araxá and Bambuí Groups (Campos \& Freitas-Silva 1998, Faria 1995). The most important minerals are iron oxides and hydroxides, gibbsite, kaolinite and quartz. The rocks of the Paranoá Group constitute 65\% of the Federal District and are widespread in the western and northwestern portions of the territory. The R3 unit (sandy metarrithmite) and the Q3 unit (medium quartzite) are responsible for keeping the high plateaus, with deep weathered mantles, sandy texture and high permeability. The Clay Metarrithmite unit and the Psamo-Pellitic Carbonate unit also produce Oxisols and Inceptisols, depending

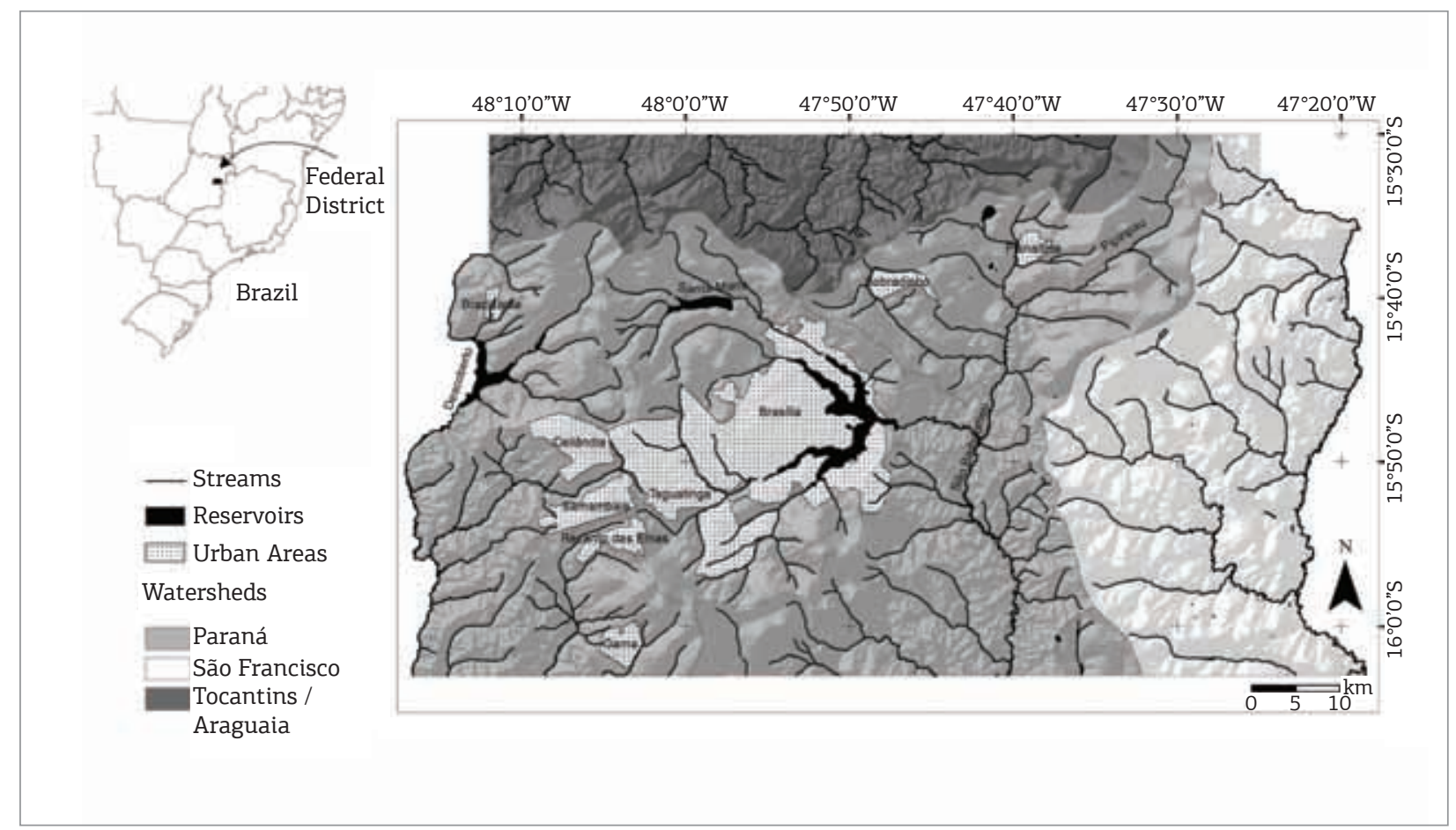

Figure 1. Location map of the study area (Federal District of Brazil). 
on the intensity of weathering and parent material. Soils derived from carbonates and pellitic rocks are thick, while quartzites are more resistant to hydrolysis. Similarly, soil texture is controlled by the parent materials: carbonates and pellitic rocks result in clayey texture; quartzites often produce sandy texture.

The Canastra Group occupies about 15\% of the area and occurs mainly in valleys of Bartolomeu River. Chlorite phyllites of this Group are commonly covered by a thick weathered soil layer, but it can also occur in hilly regions, associated with thin Inceptisols. The Araxá Group is limited to the southwestern part of the Federal District, mainly along valleys. Main rock types are schist and quartzite lens covered by a thin layer of soil in the majority of the area. The Bambuí Group is distributed throughout in the eastern portion of the Federal District, along the valleys of Preto River as well as in restricted areas in the central and northern portions (valleys of Maranhão River). The main rock types are siltstone, shale and arkoses. Outcrops of this Group can be found along streams and roads. The majority of the area is covered by thick Red Oxisols or by Inceptisols, in the case of a hilly relief.
Geomorphology controls local and regional hydrogeologic flow systems and influences the recharge and discharge and overall flow patterns. Five different compartments were recognized by Novaes Pinto (1994): High Plateau (elevation > 1,100 m; drainage density: low; topography: flat to gentle; major soil type: Oxisols); Intermediate Plateau (elevation: 850 - 1,100 m; topography: flat to gentle; major soil type: Oxisols); Incased Valley (topography: flat to gentle; drainage density: high; major soil type: Inceptisols); Soft Border (transition from High Plateau to Intermediate Plateau); and Strong Border (abrupt transition from High Plateau to Incased Valley) (Fig. 2).

Climate is also important for the Federal District's water resources availability. Besides the relatively high amount of annual rainfall (approx. 1,500 mm), there is a marked seasonality over the Federal District. The peak of the rainy summer comprises more than $50 \%$ of the rainfall from December to March. Usually there is no rainfall during the peak of the dry season (June to August). The first rainfall usually occurs in late September. This seasonal pattern is also followed by other parameters such as relative humidity (which can go down to approx. $5 \%$ in the

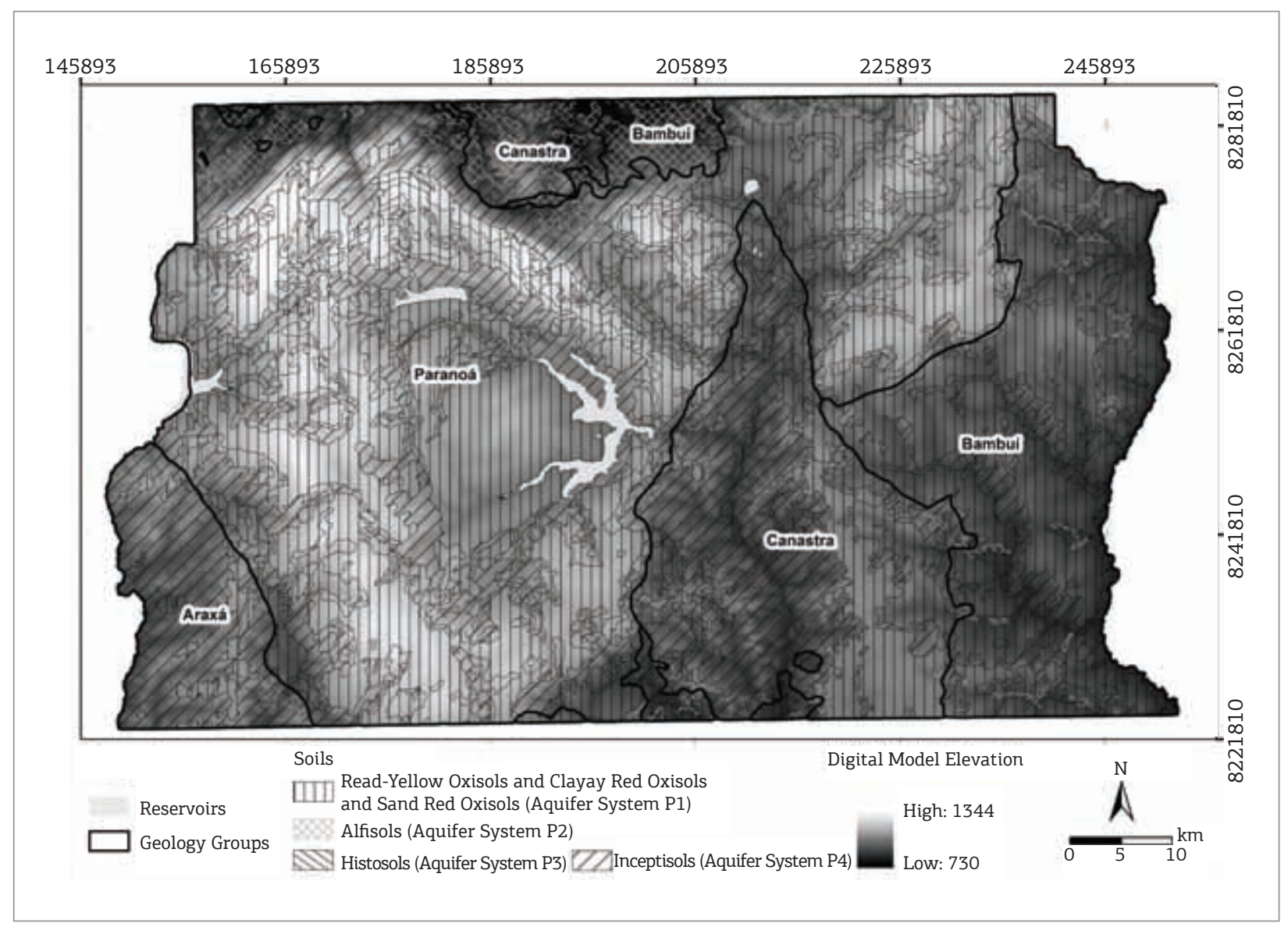

Figure 2. Geology groups, soils and elevation of the Federal District. 
hottest hours of August) and temperature (approx. $17^{\circ} \mathrm{C}$ in colder months; $>30^{\circ} \mathrm{C}$ in hotter months). Because of this seasonal climate variation, shallow aquifers play a key role in keeping streams perennial.

According to Coimbra (1987), the actual evapotranspiration is around $900 \mathrm{~mm}$ per year and $12 \%$ of total precipitation infiltrates in the soil, reaching the saturated zone of the aquifers. The presence of different classes of savanna vegetation is associated with different geomorphological compartments and includes grasslands, shrublands and forestlands. Shrublands are commonly developed in thick Oxisols, grasslands are widespread in Inceptisols and forestlands are found mainly along streams. Forestlands are important to facilitate infiltration of rainfall and for aquifer recharge due to bioturbation by roots and protection against soil erosion due to heavy rainfall.

Based on the types of weathering mantles, thickness of saturated soil layer and hydraulic conductivity, Campos and Freitas-Silva (1998) classified the Federal District's shallow aquifers into four systems: P1, P2, P3 and P4. Gonçalves et al. (2007) proposed a different approach for mapping these aquifers, which was based on new infiltration data and on curve-number theory (SCS 1954). P1, P2 and P3 systems are characterized by high thickness and high, moderate and low hydraulic conductivities, respectively. The P4 system presents low thickness and low hydraulic conductivity. Shallow wells operated in these aquifers show low average yields $\left(<800 \mathrm{~L}^{-} \mathrm{h}^{-1}\right)$. Theses aquifers feature a local groundwater flow regime and the discharge is associated with contact and slope of springs.

These shallow aquifers are important not only to act as complementary water supply of relatively isolated rural communities, but also to keep streams, rivers, springs and lakes perennial during the dry season. The unsaturated zone of these aquifers functions as an important protection factor to avoid anthropogenic contamination. As the saturated zone stays incontact with fractured aquifers, the porous aquifers, mainly the P1 and P2 systems, play an important role in their recharge.

\section{METHODS}

As mentioned before, hydraulic conductivity is a key parameter to characterize porous aquifers. Although many authors have studied it (e.g., Campos \& Freitas-Silva 1998, Souza 2001, Lousada \& Campos 2005, Almeida et al. 2006, Fiori et al. 2010), none have considered the influence of soil structure in the porous aquifers. According to Williams et al. (1992) and Danalatos et al. (1994), soil structure in tropical countries is essential to understanding the high $\mathrm{K}$-values in soil profiles with high clay contents.
To estimate K-values from porous domains of the Federal District's soils, soil structure was taken into consideration. Infiltration tests were conducted in different soil classes using the open-end-hole tests as well as the permeability tests proposed by Heitfeld (1979). Soil texture was determined in the laboratoryon soil samples. K-values were also estimated by applying pedotransfer functions available in the Rosetta software package (Schaap et al. 2001).

\section{Open-end-hole method}

Determinations of hydraulic conductivity by in situ soil permeability (infiltration) tests were used to compare field test data with the results of pedotransfer functions. Shallow boreholes were drilledto conduct unsteady-state permeability tests in unsaturated zones of soils. The evaluation of permeability tests or infiltration tests is based on Darcy's equation. Field results were evaluated using equations as proposed by Heitfeld (1979) and Scheytt and Hengelhaupt (2001). Soil samples were taken from each borehole to determine chemical composition and particle size distribution.

\section{Location And Soil Types}

Eight sites located in the surroundings of the urban areas of the Federal District, representing the main soil types found in the study area.Boreholes were drilled to obtain undisturbed, 1-meter depth soil samples (Fig. 3). Additional boreholes near sampling points were drilled in six sites at $30-50 \mathrm{~cm}$ depth and installed for in situ permeability tests in the unsaturated zone.

Due to the thickness of Inceptisols and related saprolithes, which are normally less than $1 \mathrm{~m}$ thick, infiltration tests could not be realized. Very high bulk density Alfisols are difficult to befound in the Federal District. Field investigations led to the assumption that the permeability of Alfisols depends more on structural elements like faults and cracks associated with neotectonic events than on soil porosity. Textural analyses were conducted for three depths of each borehole: $0-20 \mathrm{~cm} ; 20-50 \mathrm{~cm}$; and $50-100 \mathrm{~cm}$. The particle size distribution cannot be used for permeability estimations with conventional methods because tropical soils have high clay and silt contents. Common methods of permeability estimations of fine sand to gravel textured materials, as described by Beyer (1964), are therefore not applicable. The particle size distribution was used in this study as input parameter for pedotransfer functions.

\section{Permeability tests}

results of the infiltration tests represent the hydraulic characteristics of the sediments surrounding the boreholes. In other words, K-values for permeability are essentially 
point-based, in which accuracy is shown only for small areas surrounding the boreholes. Three types of permeability tests in open boreholes can be conducted:

constant flow rate test with change in hydraulic head in the borehole;

constant head test with stabilized infiltration rate; and

variable head test with instant change in the hydraulic test due to quick injection.

The change of hydraulic head time is measured. Stable and variable head tests were chosen as the preferable infiltration test methods. The water level above the infiltration point corresponds to the filter screen or to the open end of boreholes and varies over time.

The rate of infiltration through a soil tends to the partially saturated permeability of the soil. The soil does not reach full saturation because of the presence of a small volume of air in the porosity, for instance, associated with injected water. This may reduce the K-values measured in the field. For soils with low permeability (e.g., loamy and clayey soils), the effect of suction at the wetting front can also affect the test results, especially in unsaturated zones. Therefore, saturation of soils prior to the test itself is recommended (ISO 2012). The test was conducted with a limited saturation phase of $10-20 \mathrm{~min}$ utes, which surely did not avoid the effect of suction.

For the evaluation of field test with variable pressure height, the following equation for the open-end-hole test was used:

$$
K=\frac{\pi \cdot r^{2}}{C \cdot\left(\tau_{1}-\tau_{2}\right)} \operatorname{In} \frac{h_{1}}{h_{2}}
$$

where $\mathrm{r}=$ radius of the borehole; $\mathrm{h}_{1}, \mathrm{~h}_{2}=$ height of water column; and $\mathrm{t}=$ time. Factor $\mathrm{C}$ depends on the screen length and borehole diameter. The equation for the open end test with nominal screen length $(\mathrm{L})=0$ can be calculated by:

$$
C=5.5 \cdot r
$$

The infiltration test after Heitfeld (1979) and Earth Manual (1951, after Scheytt and Hengelhaupt, 2001) for unsaturated soils can be evaluated by the following equation:

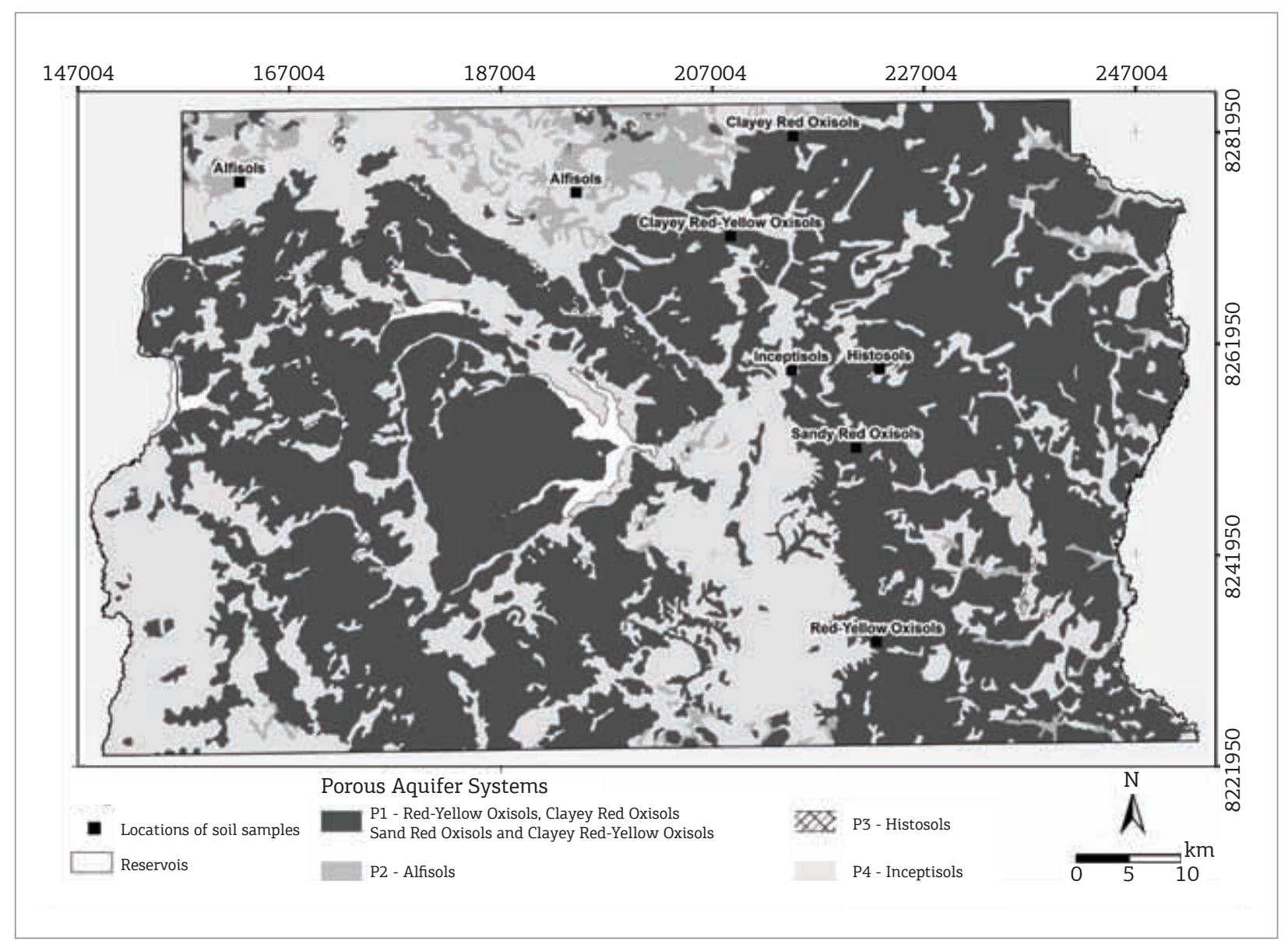

Figure 3. Porous aquifer systems and the locations of soil samples in the study area. 
$K=\frac{\pi \cdot \Delta h \cdot C t \cdot r_{a}}{C u \cdot h \cdot\left(\tau_{1}-\tau_{2}\right)}$

Correction factors for $\mathrm{Ct}$ (temperature) and $\mathrm{Cu}$ (length of filter material) can be obtained from monograms of Earth Manual (1951 after Scheytt \& Hengelhaupt 2001) (Figs. 4 and 5).

Comparing the open-end-hole test with the setup of permeability test after Heitfeld (1979), additional space at the bottom of the cased borehole is used. The space is filled with gravel and works as drainage space instead of an installed borehole with casing and screens.

\section{Pedotransfer Functions (Rosetta Software)}

PTFs are recognized as an efficient method to predict soil hydraulic properties such as water retention and hydraulic conductivity. Reviews regarding the development and the use of PTFs can be found in Rawls et al. (1991), Wösten (1997), Pachepsky and Rawls (1999), and Wösten et al. (2001). There are few references on results of research with PTFs that had used database from tropical countries. Cresswell et al. (1999) reviewed the application of PTFs to predict hydraulic properties of soils from Australia. Also in Australia, Minasny and McBratney (2002) applied the neural network method to predict the parameters of water retention of the van Genuchten (1980) equation. McKenzie and Jacquier (1997) presented a regression tree that predicts saturated hydraulic conductivity from soil morphology classes, including texture, structure and porosity. Minasny et al. (1999) predicted the parameters of the van Genuchten equation from basic soil properties and broad classes of soil texture.

In Brazil, estimations of hydraulic conductivity of kaolinitic Yellow Oxisols in the Amazonian region, based

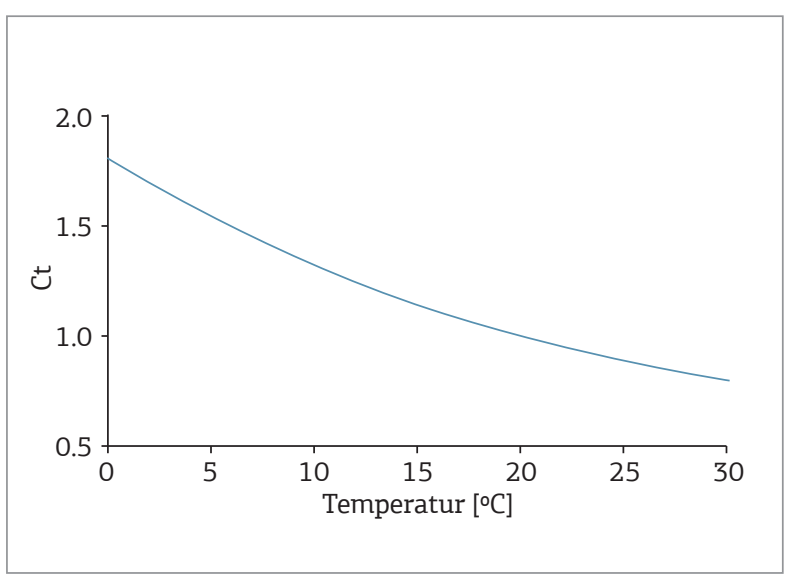

Figure 4. Correction factor for temperature (Ct). Source: Earth Manual (1951 after Scheytt \& Hengelhaupt 2001). on water retention curves, were obtained by Tomasella and Hoodnett (1997). Tomasella et al. (2000) used soil texture, organic carbon, equivalent humidity and soil density data to establish relations between the van Genuchten equation and water retention parameters. Gaiser et al. (2000) studied the influence of clay minerals in soil water retention from semiarid areas of western Africa and northwestern Brazil and showed that PTFs of soils with low activity clay minerals differ from soils with high activity clay minerals due to silt and organic carbon content. Hoodnett and Tomasella (2002) developed new PTFs for tropical soils related to water retention parameters used in the van Genuchten equation.

The van Genuchten equation was successfully applied to several different soils [e.g. soils reported by Villagra et al. (1988) and Wösten and van Genuchten (1988)]. Van den Berg et al. (1997) found that this equation describes adequately the water retention curves of soils with low activity clay minerals, commonly found in Brazilian soils. The parameters of the van Genuchten equation adapted to Brazilian soils showed high accuracy in the estimation of hydraulic conductivity, as observed by Hoodnett and Tomasella (2002).

Most of these PTFs were compiled by Schaap et al. (2001) and integrated into the Rosetta software package, which estimates the parameters of water retention and the hydraulic conductivity according to models proposed by van Genuchten (1980) and Mualem (1976). Rosetta offers five PTFs that predict hydraulic properties of the soil from limited sets of input data. Hierarchic models use the following input data: soil textural classes; percentages of sand, silt and clay, density and a point of water retention in $330 \mathrm{~cm}$ $(33 \mathrm{kPa})$ and the same parameters and water retention points in 330 and $15,000 \mathrm{~cm}$ (33 and $1500 \mathrm{kPa}$ ). The first PTF

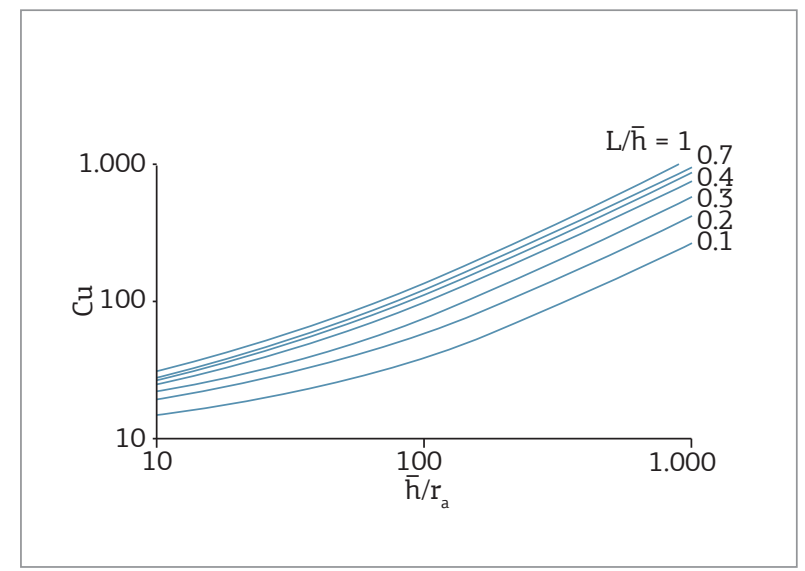

Figure 5. Correction factor for length of filter material (Cu). Source: Earth Manual (1951 after Scheytt \& Hengelhaupt 2001). 
is based on average hydraulic parameters for varying types of soil texture. Other four models are based on analyses of neural network and usually provide more accurate forecasts, depending on the quality of the input data. Besides the hierarchical approach, the model provides prediction of hydraulic conductivity based on van Genuchten (1980) and Mualem (1976).

In this study, 25 soil profiles from the Brazilian Soil Survey (Soil Map of the Federal District - Embrapa 1978) were used to estimate unsaturated K-values by applying PTFs available in the Rosetta software. Six types of more representative soils found in the study area (Red Oxisols, Red-Yellow Oxisols, Alfisols, Inceptisols and Histosols) were described according to the textural and structural variations of each diagnostic horizon. In order to estimate the hydraulic conductivity more appropriately and to adapt the PTFs for soils of the Federal District, values of soil density (Dd) and gravimetric water contents (W)were obtained. PTFs developed by Benites et al. (2007), shown in equation (4) and Tomasella et al. (2003), shown in equation (5), are the most approximated equations:

$\mathrm{Dd}=1.66141-0.12455 \mathrm{~N}-0.00042 \mathrm{Clay}+0.10622 \mathrm{SB}-$ $0.00059 \mathrm{Fe}_{2} \mathrm{O}_{3}-0.00328 \mathrm{C}: \mathrm{N}+0.00011 \mathrm{WDC}+0.00041$ $\mathrm{Al}_{2} \mathrm{O}_{3}-0.09597(\mathrm{Ca}+\mathrm{Mg})$

where $\mathrm{N}=$ total nitrogen (\%); Clay = percentage; $\mathrm{SB}=$ bulk bases $\left(\mathrm{Ca}^{2++} \mathrm{Mg}^{2++} \mathrm{K}^{+}, \mathrm{mE} / 100 \mathrm{~g} ; \mathrm{Fe}_{2} \mathrm{O}_{3}=\mathrm{mE} / 100 \mathrm{~g}\right.$; $\mathrm{WDC}=$ clay dispersed in water $(\%) ; \mathrm{Al}_{2} \mathrm{O}_{3}=$ percentage; and $\mathrm{Ca}+\mathrm{Mg}=\mathrm{mE} / 100 \mathrm{~g}$.

The PTF used to estimate the water retention parameters from van Genuchten's equations in the range between $-33 \mathrm{kPa}$ (W33) and $-1500 \mathrm{kPa}$ (W1500) is as follow (Tomasella et al. 2003):
$\mathrm{X}_{14}=-1.05501+0.0650857 \mathrm{SI}$

$X_{15}=-2.07588+0.0423954 \mathrm{CL}$

$\mathrm{X}_{16}=-6.03402+4.80572 \mathrm{Db}$

$X_{17}=-2.18409+8.84963 \mathrm{Me}$

$Z_{9}=0.175202+1.18513 x_{17}-0.0996042\left(x_{17}\right)^{2}+0.327915 x_{16}$

$-0.0758657\left(x_{16}\right)^{2}$

$\mathrm{Z}_{10}=0.929344 \mathrm{z}_{9}+0.132519 \mathrm{x}_{14}$

$\mathrm{W}_{10 \mathrm{kPa}}=0.339255+0.112526 \mathrm{z}_{10}$

$\mathrm{Z}_{11}=0.191452+1.25652 \mathrm{x}_{17}-0.079098\left(\mathrm{x}_{17}\right)^{2}+0.393814 \mathrm{x}_{16}$ $+0.152095 \mathrm{x}_{17} \mathrm{x}_{16}$

$\mathrm{W}_{33 \mathrm{kPa}}=0.28951+0.103815 \mathrm{z}_{11}$

$Z_{13}=0.235084+0.33033 x_{15}-0.191838\left(x_{15}\right)^{2}+$

$0.0543679\left(\mathrm{x}_{15}\right)^{3}+0.977685 \mathrm{x}_{17}+0.304174 \mathrm{x}_{15} \mathrm{x}_{17}-$

$0.218857\left(\mathrm{x}_{17}\right)^{2}-0.164373 \mathrm{x}_{15}\left(\mathrm{x}_{17}\right)^{2}+0.0415057\left(\mathrm{x}_{17}\right)^{3}+$

$0.373361 \mathrm{x}_{16}+0.0811861 \mathrm{x}_{17} \mathrm{x}_{16}-0.0768087 \mathrm{x}_{15} \mathrm{x}_{17} \mathrm{x}_{16}$

$\mathrm{W}_{1500 \mathrm{kPa}}=0.214008+0.0862945 \mathrm{z}_{13}$

where CS = coarse sand (\%); FS = fine sand (\%); SI = silt $(\%) ; \mathrm{CL}=$ clay $(\%)$; $\mathrm{Db}=$ bulk density $\left(\mathrm{g} . \mathrm{cm}^{-3}\right) ; \mathrm{Me}=$ moisture equivalent (\%); $\mathrm{W}_{10 \mathrm{kPa}}, \mathrm{W}_{33 \mathrm{kPa}}, \mathrm{W}_{1500 \mathrm{kPa}}$ gravimetric water content at 10,33 , and $1500 \mathrm{kPa}$, respectively $\left(\mathrm{g} \cdot \mathrm{g}^{-1}\right) ; \mathrm{X}_{14}-$ $X_{17}$ and $Z_{9}-Z_{11}$ and $Z_{13}$, auxiliary variables.

Reference PTFs were chosen according to the following criteria:

involving only textural properties;

- being developed from a vast amount of samples of Brazilian soils; and

- having been extensively evaluated in terms of its applicability.

\section{RESULTS AND DISCUSSIONS}

To reach the objectives of this study, the main classes of soils from the Federal District were characterized in terms

Table 1. Textural and structural characterization of major soil types from Federal District.

\begin{tabular}{|c|c|c|c|c|}
\hline $\begin{array}{l}\text { Soils from } \\
\text { Embrapa (1978) + } \\
\text { field observation }\end{array}$ & $\begin{array}{l}\text { Number of } \\
\text { Profiles }\end{array}$ & $\begin{array}{l}\text { Diagnostic } \\
\text { Horizon (30 cm } \\
\text { depth) }\end{array}$ & Texture & Structure \\
\hline $\begin{array}{l}\text { Red Oxisols + Red- } \\
\text { Yellow Oxisols }\end{array}$ & 11 & B latosolic & $\begin{array}{l}\text { sandy; loamy sandy; sandy loamy; } \\
\text { sandy clay loam; sandy clay; clay } \\
\text { with or without limestone in depth }\end{array}$ & $\begin{array}{c}\text { Granular / little / weak to } \\
\text { strong }\end{array}$ \\
\hline Red Alfisols & 8 & $\begin{array}{l}\text { B nitic and } \\
\text { B textural }\end{array}$ & $\begin{array}{c}\text { clay; clay loam; silty clay loam; } \\
\text { silty clay }\end{array}$ & $\begin{array}{c}\text { Sub angular block prismatic or } \\
\text { laminar / moderate / strong } \\
\text { Simple grain or massive }\end{array}$ \\
\hline Histosols & 2 & B histic and Gley & clay; medium loam & Prismatic \\
\hline Inceptisols & 4 & B incipient & $\begin{array}{l}\text { clay; medium loam; silty loam; } \\
\text { silty clay loam }\end{array}$ & Block / moderate / little \\
\hline
\end{tabular}


of textural and structural features observed in field and described by Embrapa (1978) (Tab. 1, Fig. 6). The diagnostic horizons (approx. $30 \mathrm{~cm}$ depth) were considered as the basis for each profile classification.

The results demonstrated a significant increase of clayey texture at a depth of between 50 and $100 \mathrm{~cm}$ in Oxisols. Profiles showed that more than $50 \%$ of Oxisols have clayey texture. Such characteristics reveal strong development of finer granular structure in Oxisols, which reflects the high macroporosity of these soils. In average, these soils present $30 \%$ of sand, $10 \%$ of silt and $50 \%$ of

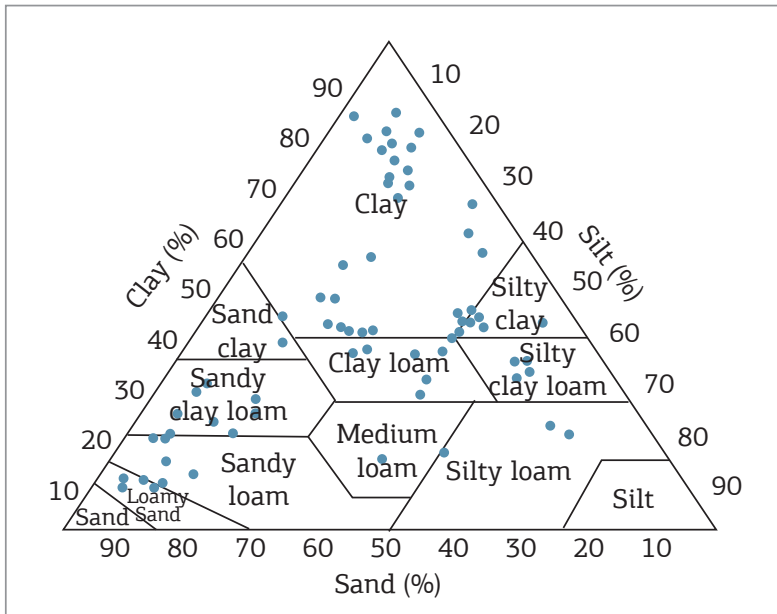

Figure 6. Triangular textural classification of the soils applied in the study (data source: Lemos \& Santos 1984). clay. Alfisols also indicated the increase of clayey texture but in a lesser extent in relation to Oxisols. These soils present about $30 \%$ of sand, silt and clay for all horizons and are also structured in blocks, with strong aggregation. The clayey texture is more apparent in the first $20 \mathrm{~cm}$ of Histosols and Inceptisols. These soils have slight decrease of clay content between 20 and $50 \mathrm{~cm}$. These soils did not occur at depths higher than $50 \mathrm{~cm}$. The structures of these soils are prismatic, in blocks and, in some cases, massive.

\section{Open-End-Hole and \\ Permeability Test after Heitfeld (1979)}

Results for open-end-hole tests and permeability tests after Heitfeld (1979) showed good correlation. The highest difference between the two methods was found in the site ID 6 (14\%). Results for P1, P2, and P4 hydrogeological systems allowed estimating permeability values for different soils types, including Histosols and Alfisols. The hydraulic conductivity of these soils ranged from $10^{-8}$ to $10^{-6} \mathrm{~m} \cdot \mathrm{s}^{-1}$ (Tab. 2).

Because of the amount of field tests, comparison between the results of this study and those obtained by previous investigations in the Federal District and in Goiás State was necessary. Souza and Campos (2001), Reatto et al. (2007) and Fiori et al. (2010) reported K-values of soils based on in situ infiltration tests and laboratory tests. Souza and Campos (2001) directly referred the results to the hydrogeologic units P1 to P4. Mean values of these studies of comparable depths and soils were taken to visualize differences in results obtained by these studies and current study (Fig. 7).

Table 2. Results of hydraulic conductivity $(\mathrm{K})$ values obtained by open-end-hole and permeability tests after Heitfeld (1979).

\begin{tabular}{|c|c|c|c|c|c|}
\hline \multirow{2}{*}{ Soil Type } & \multirow{2}{*}{ ID } & \multirow{2}{*}{$\begin{array}{l}\text { Depth of Test } \\
\text { (cm) }\end{array}$} & \multirow{2}{*}{$\begin{array}{l}\text { Aquifer } \\
\text { System }\end{array}$} & \multicolumn{2}{|c|}{$\begin{array}{l}\text { Hydraulic Conductivity } \\
\qquad \mathrm{K}(\mathrm{m} / \mathrm{s})\end{array}$} \\
\hline & & & & Open-end-hole method & $\begin{array}{c}\text { Permeability test after } \\
\text { Heitfeld (1979) }\end{array}$ \\
\hline Red-Yellow Oxisols & 5 & $30-50$ & $\mathrm{P} 1$ & $1.93 * 10^{-6}$ & $1.37 * 10^{-6}$ \\
\hline Red Clay Oxisols & 6 & $30-50$ & $\mathrm{P} 1$ & $4.5 * 10^{-7}$ & $3.1 * 10^{-6}$ \\
\hline Red Sandy Oxisols & E5 & $30-50$ & $\mathrm{P} 1$ & $1.43 * 10^{-6}$ & $3.02 * 10^{-6}$ \\
\hline Red-Yellow Clay Oxisols & SS & $30-50$ & $\mathrm{P} 1$ & $2.79 * 10^{-6}$ & $6.21 * 10^{-7}$ \\
\hline Inceptisols & 4 & - & P4 & \multicolumn{2}{|c|}{ Infiltration test not applicable } \\
\hline Alfisols & 2 & $30-50$ & $\mathrm{P} 2$ & $6.28 * 10^{-7}$ & $1.87 * 10^{-6}$ \\
\hline Red Alfisol & 3 & - & $\mathrm{P} 2$ & \multicolumn{2}{|c|}{ Infiltration test not applicable } \\
\hline Histosols & 7 & $30-50$ & P3 & $3.4 * 10^{-8}$ & $1.1 * 10^{-8}$ \\
\hline
\end{tabular}


There was a good approximation with the results obtained by Reatto et al. (2007). K-values obtained by Souza and Campos (2001) were around one decimal power higher. K-values from Fiori et al. (2010) matched at good to very good approximation when compared with the soils characteristics observed in situ.

\section{K-values Obtained by the Rosetta Method}

K-values from Embrapa's data were obtained after adapting PTFs for the Federal District's soils by using appropriated values of soil bulk density $(\mathrm{Db})$ and gravimetric water content in the Rosetta software (Tab. 3). Db of Oxisols ranged from 1.44 to $1.92 \mathrm{~g} . \mathrm{cm}^{-3}$. Db from Alfisols ranged from 1.62 to 1.79 g. $\mathrm{cm}^{-3}$. Finally, Db from Inceptisols and Histosols ranged from 1.60 to $1.65 \mathrm{~g} . \mathrm{cm}^{-3}$. There was an increase of $\mathrm{Db}$ values with increasing depth in most of soil profiles which can be explained by the increase of clay content and consequent decrease of total porosity and hydraulic conductivity. Gravimetric water contents at $-33 \mathrm{kPa}$ (W33) and $-1500 \mathrm{kPa}$ (W1500) from Oxisols

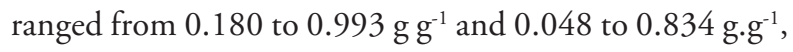
respectively. For Alfisols, gravimetric water contents ranged from 0.049 to $0.514 \mathrm{~g} . \mathrm{g}^{-1}$ and from 0.004 to $0.196 \mathrm{~g} . \mathrm{g}^{-1}$ for the W33 and W1500, respectively.
Gravimetric water contents from Inceptisols and Histosols ranged from 0.272 to $0.466{\mathrm{~g} . \mathrm{g}^{-1}}^{-1}$ and from 0.079 to $0.161 \mathrm{~g} . \mathrm{g}^{-1}$, respectively. In general, these results showed that the percentage of variance gradually decreased from 73 to $26 \%$ in Oxisols, from 75 to $25 \%$ in Alfisols, and from 75 to $24 \%$ in Inceptisols and Histosols. It is related to the decrease in the proportion of porosity that retains water when the water potential decreases. The same evidence was noticed for varying soil types considered by Bruand et al. (1988), Dexter (2004), and Reatto et al. (2007).

$\mathrm{K}$-values calculated for Oxisols ranged from $3.44^{*}$ $10^{-6}$ to $1.71 * 10^{-7} \mathrm{~m} . \mathrm{s}^{-1}$ in surface zone and from $2.08 * 10^{-6} \mathrm{~m} . \mathrm{s}^{-1}$ to $2.53 * 10^{-7} \mathrm{~m} \cdot \mathrm{s}^{-1}$ in deeper zones. For Alfisols, they ranged from $1.45^{*} 10^{-6}$ to $5.73^{*}$ $10^{-8} \mathrm{~m} . \mathrm{s}^{-1}$ in surface zone and $2.88^{*} 10^{-5}$ to $4.25^{*}$ $10^{-8} \mathrm{~m} \cdot \mathrm{s}^{-1}$ in deep zone. Inceptisols and Histosols ranged from $1.28 * 10^{-6}$ to $8.96 * 10^{-8} \mathrm{~m} \cdot \mathrm{s}^{-1}$ in surface zone and from $6.33^{*} 10^{-7}$ to $9.15^{*} 10^{-8} \mathrm{~m} . \mathrm{s}^{-1}$ in deeper zones (Tab. 4). Again, these results showed a decreasing trend of K-values with depth due to the decrease of porosity and the increase of clay contents in Oxisols. This was also observed in estimations based on tests after Heitfeld. Furthermore, these soils commonly occur in high plateaus (chapadas). When found in natural conditions,

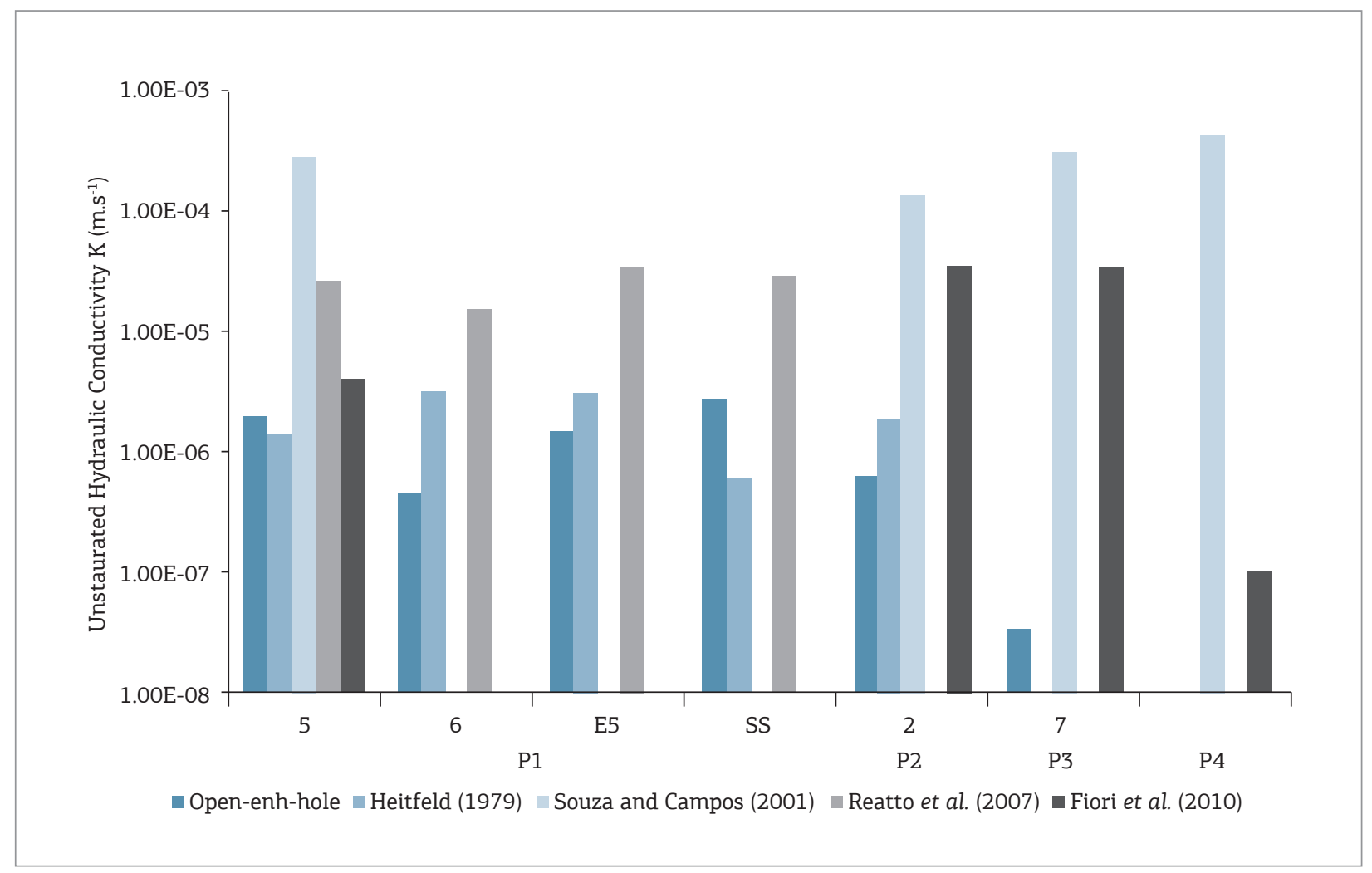

Figure 7. Comparison of K-values of soils from the Federal District and Goiás State obtained by different authors. 
they impose a great control of conditions of infiltration, regardless of the parent material.

High correlations were also observed in aquifers belonging to P2 system. Hydraulic conductivity from Alfisols showed a similar range of values which was observed in tests after Heitfeld (1979) and by the Rosetta software. The average value estimated by Rosetta was $3.57^{*} 10^{-6} \mathrm{~m} . \mathrm{s}^{-1}$, while the value observed on the tests after Heitfeld was $1.87 * 10^{-6} \mathrm{~m} . \mathrm{s}^{-1}$. The behavior of this soil class was depth-dependent. There were both increase and decrease of hydraulic conductivity in depth, but Alfisols showed the same behavior. It followed the expected pattern: clay content increased with depth and this led to a decrease in hydraulic conductivity.

As noticed by previous studies (Souza \& Campos 2001, Cadamuro et al. 2002, Fiori et al. 2010) and also by this study, Inceptisols presented the least favorableconditions of infiltration and drainage. These soils are poorly developed, derived from low-degree metasedimentary rocks, and occur in hilly regions (intense runoff and limited infiltration). Based on infiltration tests and on comparison and addition of data derived by previous studies, Tab. 4 shows K-values for different aquifer systems. These are considered the typical values for the different

Table 3. Bulk density (Db), gravimetric water content (W) and hydraulic conductivity obtained from PTFs developed by Benites et al. (2007) and Tomasella et al. (2003), based on Rosetta software, and on Embrapa's data.

\begin{tabular}{|c|c|c|c|c|c|c|c|c|c|}
\hline \multirow{3}{*}{$\begin{array}{l}\text { Aquifer } \\
\text { System }\end{array}$} & \multirow{3}{*}{$\begin{array}{l}\text { Soil } \\
\text { Type }\end{array}$} & \multicolumn{2}{|c|}{$\begin{array}{l}\text { Bulk Density (Db) } \\
\text { g.cm }\end{array}$} & \multicolumn{2}{|c|}{$\begin{array}{l}\text { Gravimetric Water } \\
\text { Content (W33) g.g }\end{array}$} & \multicolumn{2}{|c|}{$\begin{array}{l}\text { Gravimetric Water } \\
\text { Content (W1500) g.g }\end{array}$} & \multicolumn{2}{|c|}{$\begin{array}{c}\text { Hydraulic } \\
\text { Conductivity (K) } \\
\left(\mathrm{m} . \mathrm{s}^{-1}\right)\end{array}$} \\
\hline & & Surface & $\begin{array}{l}\text { Deeper } \\
\text { Zone }\end{array}$ & Surface & $\begin{array}{l}\text { Deeper } \\
\text { Zone }\end{array}$ & Surface & $\begin{array}{l}\text { Deeper } \\
\text { Zone }\end{array}$ & Surface & $\begin{array}{l}\text { Deeper } \\
\text { Zone }\end{array}$ \\
\hline & & $(0-50 \mathrm{~cm})$ & $(>50 \mathrm{~cm})$ & $(0-50 \mathrm{~cm})$ & $(>50 \mathrm{~cm})$ & $(0-50 \mathrm{~cm})$ & $(>50 \mathrm{~cm})$ & $(0-50 \mathrm{~cm})$ & $(>50 \mathrm{~cm})$ \\
\hline $\mathrm{P} 1$ & $\mathrm{RO}$ & 1.70 & 1.62 & 0.603 & 0.472 & 0.335 & 0.168 & $1.71 \mathrm{E}^{-7}$ & $2.52 \mathrm{E}^{-7}$ \\
\hline P1 & RO & 1.60 & 1.60 & 0.332 & 0.332 & 0.100 & 0.100 & $1.07 \mathrm{E}^{-6}$ & $1.12 \mathrm{E}^{-6}$ \\
\hline P1 & RO & 1.54 & 1.60 & 0.335 & 0.334 & 0.098 & 0.101 & $1.41 \mathrm{E}^{-6}$ & $1.01 \mathrm{E}^{-6}$ \\
\hline P1 & RO & 1.58 & 1.57 & 0.452 & 0.444 & 0.154 & 0.148 & $4.83 \mathrm{E}^{-7}$ & $6.37 \mathrm{E}^{-6}$ \\
\hline P1 & RYO & 1.54 & 1.60 & 0.325 & 0.442 & 0.135 & 0.136 & $7.99 \mathrm{E}^{-7}$ & $6.05 \mathrm{E}^{-7}$ \\
\hline P1 & RYO & 1.59 & 1.60 & 0.452 & 0.475 & 0.154 & 0.167 & $4.31 \mathrm{E}^{-7}$ & $3.12 \mathrm{E}^{-7}$ \\
\hline $\mathrm{P} 1$ & RYO & 1.60 & 1.63 & 0.237 & 0.252 & 0.067 & 0.073 & $3.44 \mathrm{E}^{-6}$ & $2.08 \mathrm{E}^{-6}$ \\
\hline P2 & $\mathrm{A}$ & 1.64 & 1.65 & 0.327 & 0.376 & 0.100 & 0.121 & $3.74 \mathrm{E}^{-7}$ & $1.81 \mathrm{E}^{-7}$ \\
\hline P2 & A & 1.62 & 1.63 & 0.130 & 0.105 & 0.033 & 0.024 & $1.45 \mathrm{E}^{-6}$ & $2.88 \mathrm{E}^{-6}$ \\
\hline $\mathrm{P} 2$ & $\mathrm{~S}$ & 1.65 & 1.64 & 0.175 & 0.158 & 0.047 & 0.042 & $6.38 \mathrm{E}^{-6}$ & $7.62 \mathrm{E}^{-6}$ \\
\hline P2 & A & 1.69 & 1.70 & 0.446 & 0.476 & 0.157 & 0.175 & $5.73 \mathrm{E}^{-8}$ & $4.25 \mathrm{E}^{-8}$ \\
\hline P2 & A & 1.71 & 1.66 & 0.464 & 0.470 & 0.169 & 0.168 & $7.97 \mathrm{E}^{-8}$ & $1.01 \mathrm{E}^{-7}$ \\
\hline $\mathrm{P} 2$ & $\mathrm{~S}$ & 1.75 & 1.69 & 0.406 & 0.345 & 0.141 & 0.112 & $9.24 \mathrm{E}^{-8}$ & $5.07 \mathrm{E}^{-7}$ \\
\hline P3 & $\mathrm{H}$ & 1.61 & 1.63 & 0.230 & 0.326 & 0.106 & 0.102 & $1.28 \mathrm{E}^{-6}$ & $6.32 \mathrm{E}^{-7}$ \\
\hline $\mathrm{P} 4$ & $\mathrm{I}$ & 1.64 & 1.64 & 0.407 & 0.438 & 0.134 & 0.147 & $1.61 \mathrm{E}^{-7}$ & $9.14 \mathrm{E}^{-8}$ \\
\hline $\mathrm{P} 4$ & I & 1.62 & - & 0.450 & - & 0.153 & - & $8.95 \mathrm{E}^{-8}$ & - \\
\hline P4 & I & 1.63 & - & 0.344 & - & 0.107 & - & $4.31 \mathrm{E}^{-7}$ & - \\
\hline
\end{tabular}

RO: Red Oxisols; RYO: Red Yellow Oxisols; A: Alfisols; H: Histosols; I: Inceptisols.

Table 4. Porous aquifer systems, soil types and K-values of Federal District soils.

\begin{tabular}{l|c|c|c}
\hline \multirow{2}{*}{ Aquifers Systems } & Soil Type & \multicolumn{2}{|c}{ Hydraulic Conductivity $\mathbf{( k )}\left(\mathbf{m} . \mathbf{s}^{-\mathbf{1}}\right)$} \\
\cline { 3 - 4 } & Red-Yellow Oxisols & $\begin{array}{c}\text { Surface } \\
(\mathbf{0}-\mathbf{5 0} \mathbf{~ c m})\end{array}$ & $\begin{array}{c}\text { Deeper Zone } \\
(>\mathbf{5 0} \mathbf{~ c m})\end{array}$ \\
\hline P1 & Red Clayey Oxisols & $10^{-5}-10^{-6}$ & $10^{-6}$ \\
\hline P1 & Red Sandy Oxisols & $10^{-6}$ & $10^{-7}$ \\
\hline P1 & Red-Yellow Clayey Oxisols & $10^{-5}-10^{-6}$ & $10^{-6}$ \\
\hline P1 & Inceptisols & $10^{-6}$ & $10^{-7}$ \\
\hline P4 & Red Alfisols & $10^{-6}$ & $10^{-7}$ \\
\hline P2 & Alfisols & $10^{-7}$ & $10^{-7}$ \\
\hline P2 & Histosols & $10^{-7}$ & $10^{-8}$ \\
\hline P3 & & $10^{-7}-10^{-8}$ & \\
\hline
\end{tabular}


shallow aquifers and the best fit between the parameters and aquifer types.

\section{CONCLUSIONS}

Good correlation between observed and estimated data was found when field permeability tests and PTF methods were used. Values of the P1, P2, P3 and P4 hydrogeological systems varied from $10^{-8} \mathrm{~ms}^{-1}$ to $10^{-6} \mathrm{~ms}^{-1}$. Highest $\mathrm{K}$-values were found in Oxisols, while lowest rates were found in Inceptisols. A decreasing conductivity trend was noticed as soil depth increased, mainly due to the presence of materials with loamy texture.

Contrary to the previous studies, results obtained from the Rosetta software indicated that porous aquifers of the Federal District are anisotropic, once the K-values changing in space (vertically and also in different points for the same soil type), i.e. vertical and horizontal conductivity are commonly different. This evidence is related to variations of K-values within a single class of soil. Heterogeneity of porous aquifers is conditioned by the texture, structure and macroporosity of soils. On the other hand, anisotropic behavior of soil layers can influence the behavior of porous aquifers significantly. Depending on parent material, structural elements (for instance, faults and fractures), and geomorphological characteristics, different vertical water flows during the recharge can induce variable rates of inward flow.

The thickness of porous aquifers in the Federal District ranged from few centimeters to $80 \mathrm{~m}$, with predominance (> 60\%) of thickness between $15-25 \mathrm{~m}$. P1 and P2 systems presented thickness higher than $20 \mathrm{~m}$. The thickness of $\mathrm{P} 3$ system was lower than $10 \mathrm{~m}$ and, for the P4 system, lower than $1 \mathrm{~m}$. In this system, the lack of saturation zone is common in saprolites, especially when developed on clayey rocks. Inceptisols usually have low K-values because their unsaturated zone lays directly on the rocky substratum.

\section{ACKNOWLEDGMENTS}

The authors would like to thank Prof. Edson Eyji Sano for English correction. The authors are also thankful for the funding by CNPq (Fellowships 2009/2010), and the IWASAgua/DF Project for their support in the data acquisition.

\section{REFERENCES}

Almeida L., Resende L., Rodrigues A.P., Campos J.E.G. (eds.) 2006. Hidrogeologia do Estado de Goiás.Superintendência de Geologia e Mineração. Governo do Estado de Goiás. Brazil. 230 p.

Benites V.M., Machado P.L.O.A., Fidalgo E.C.C., Coelho M.R., Madari B.E. 2007. Pedotransfer functions for estimating soil bulk density from existing soil survey reports in Brazil. Geoderma, 139:90-97.

Beyer W. 1964. Zur Bestimmung der Wasserdurchlässigkeit von Kiesen und Sanden aus der Kornverteilungskurve. WasserwirtschWassertechn, 14:165-168.

Bouma J. \& Van Lanen J.A.J. 1987. Transfer functions and threshold values: from soil characteristics to land qualities. In: BEEK, K.J. et al. (eds.). Quantified Land Evaluation. Proc. Workshop ISSS and SSSA, Washington, D.C., April 27-May 2, 1986. Int. Inst. Aerospace Surv. and Earth Sci. Publ. 6, ITC, Enschede, The Netherlands, p. 106-110.

Brooks R.H.\& Corey A.T. 1964. Hydraulic Properties of Porous Media. Civil Engineering Dept., Colorado State University, Fort Collins, CO, Hydrological Paper 3, 27 p.

Bruand A., Tessier D., Baize D. 1988. Contribution à l'étude des propriétés de rétention en eau des sols argileux: importance de la prise en compte de l'organisation de la phase argileuse. Comptes Rendus de l'Académie des Sciences, 307:1937-1941.

Cadamurro A.L.M. 2002. Aquíferos Fraturados. Proposta, Avaliação e Aplicabilidade de Técnicas de Recarga Artificial para Condomínios Residenciais do Distrito Federal. Dissertação de Mestrado, Instituto de Geociências, Universidade de Brasília, Brasília, 130 p.

Campos J.E.G.\& Freitas-Silva F.H. 1998. Hidrogeologia do Distrito Federal. In: Inventário Hidrogeológico e dos Recursos Hídricos Superficiais do Distrito Federal. IEMA / SEMATEC / UnB, Brasília, Brazil, p.1-84.
Codeplan 1995. O relatório técnico sobre a nova capital da república, $4^{a}$ ed. Codeplan, Companhia do Desenvolvimento do Planalto Central. Brasília, Brazil, 316 p.

Coimbra A.R.S.R. 1987. Balanço hídrico preliminar do Distrito Federal. In: Inventário Hidrogeológico do Distrito Federal. GDF/ CAESB, Brasília, Brazil, p.50-78.

Cresswell H.P., Mckenzie N.J., Paydar Z. 1999. A strategy for determination of hydraulic properties of Australian soil using direct measurement and pedotransfer functions. In: Van Genuchten, M.Th., Leij, F.., Wu, L. (eds). Characterization and Measurement of the Hydraulic Properties of Unsaturated Porous Media. Riverside, CA: University of California, p. 1143-1159.

Danalatos N.G., Kosmas C.S., Driessen P.M., Yassoglou N. 1994. Estimation of the draining soil moisture characteristic from standard data as recorded in routine soil surveys. Geoderma, 64:155-165.

Dexter A.R. 2004. Soil physical quality: Part I. Theory, effects of soil texture, density, and organic matter, and effects on root growth. Geoderma, 120:201-214

Embrapa 1978. Levantamento de Reconhecimento dos Solos do Distrito Federal. Boletim Técnico n53. Rio de Janeiro, Brazil, 455 p.

Embrapa 2006. Sistema Brasileiro de Classificação de Solos. 2.ed.,Embrapa - Centro Nacional de Pesquisa de Solos, Rio de Janeiro, Brazil, 412 p.

Faria A. 1995. Estratigrafia e sistemas deposicionais do Grupo Paranoá nas áreas de Cristalina, Distrito Federal e São João D’Aliança - Alto Paraíso de Goiás. Tese de Doutorado, Instituto de Geociências, Universidade de Brasília, Brasília,199 p.

Fiori J.P.O., Campos J.E.G., Almeida L. 2010. Variabilidade da condutividade hidráulica das principais classes de solos do Estado de Goiás. Geociências,29(2):229-235. 
Gaiser T., Graef F., Cordeiro J.C. 2000. Water retention characteristics of soils with contrasting clay mineral composition in semi-arid tropical regions. Australian Journal of Soil Research, 38(3):523-526.

Gonçalves T.D., Roig H. L., Campos J.E.G. 2009. Sistema de informação geográfica como ferramenta de apoio à outorga dos recursos hídricos subterrâneos no Distrito Federal.RevistaBrasileira de Geociências39(1):169-180.

Heitfeld K.H. 1979. Durhlassigkeitsuntersuchungen mittels. WDTest.-Mitt. Ing.- u. Hydrogeology, 9:175-218.

Hoodnett M.G. \& Tomasella J. 2002. Marked differences between van Genuchten soil water-retention parameters for temperate and tropical soils: a new water-retention pedo-transfer function developed for tropical soils. Geoderma, 108:155-180.

IBGE. 2012. Instituto Brasileiro de Geografia e Estatística. Atlas do Censo Demográfico 2010 Disponível em: http://www.ibge.gov.br/ home/estatistica/populacao/censo2010.Acesso em: 03/06/2012

ISO. 2012. Geotechnical investigation and testing, Geohydraulic testing, Part 2: Water permeability tests in a borehole using open systems, Final Draft, ISO/FDIS 22282-2:2012(E).

Lemos R.C.\& Santos R.D. 1984. Manual de descrição e coleta de solo no campo. 2. ed. Sociedade Brasileira de Ciência do Solo, EMBRAPASNLCS, Campinas, Brazil, $46 \mathrm{p}$.

Lousada E.O. \& Campos J.E.G. 2005. Proposta de modelos hidrogeológicos conceituais aplicados aos aquíferos da região do Distrito Federal. Revista Brasileira de Geociências, 35(3):407-414.

Mckenzie N.J. \& Jacquier D.W. 1997. Improving the field estimation of saturated hydraulic conductivity in soil survey. Australian Journal of Soil Research, 35:803-825.

Minasny B. \& Mcbratney A.B. 2002.The neuro-m method for fitting neural network parametric pedotransfer functions. Soil Science Society of American Journal, 66:352-361.

Minasny B., Mcbratney A.B., Bristow K.L. 1999. Comparison of different approaches to the development of pedotransfer functions for water-retention curves. Geoderma, 93:225-253.

Mualem Y. 1976. A new model predicting the hydraulic conductivity of unsaturated porous media. Water Resources Research, 12(3):513-522.

Novaes Pinto M. 1994. Caracterização geomorfológica do Distrito Federal. In: Novaes Pinto, M. (org). Cerrado: Caracterização, Ocupação e Perspectivas. Ed. UnB. 2.ed., Brasília,Brazil,p. 285-320.

Oliveira L.B., Ribeiro M.R., Jacomine P.K.T., Rodrigues J.J.V., Marques F.A. 2002. Funções de pedotransferência para predição da umidade retida a potenciais específicos em solos do estado de Pernambuco. Revista Brasileira de Ciências de Solo, 26(2):315-323.

Pachepsky Y. A. \& Rawls W.J. 1999. Accuracy and reliability of pedotransfer functions as affected by grouping soils. Soil Science Society of American Journal, 63(6):1748-1756.

Rawls W. J., Gish T.J., Brakensiek D.L. 1991. Estimating soil water retention from soil physical properties and characteristics. Advances in Soil Science, 16:213-234.

Reatto A., Bruand A., Silva E.M., Martins E.S., Brossard M. 2007. Hydraulic properties of the diagnostic horizon of Latosols of a regional toposequence across the Brazilian Central Plateau. Geoderma, 139:51-59.
Schaap M.G.. Leij FJ.. Van Genuchten M.Th. 2001. Rosetta: a computer program for estimating soil hydraulic parameters with hierarchical pedotransfer functions. Journal of Hydrology, 251:163-176.

Scheytt T. \& Hengelhaupt F. 2001. Auffüllversuche in der wassergesättigten und ungesättigten Zone - ein Vergleich unterschiedlicher Verfahren. Grundwasser, 6(2):71-80.

SCS. 1954. Soil Conservation Service. Hydrology Guide for Use in Watershed Planning. NRCS NationalEngineeringHandbook,Section 4. USDA. Washington DC

SEDUH. 2006. Secretaria de Estado de Desenvolvimento Urbano e Habitação. Diagnóstico Preliminar dos Parcelamentos Urbanos Informais no Distrito Federal. Brasília, Brazil, 66p.

Souza M.T.\& Campos J.E.G. 2001. O papel dos regolitos nos processos de recarga de aquíferos do Distrito Federal. Revista Escola de Minas, 54(3):315-323.

Souza M.T. 2001. Fundamentos para Gestão dos Recursos Hídricos Subterrâneos do Distrito Federal. Dissertação de Mestrado, Instituto de Geociências, Universidade de Brasília, Brasília, 94p.

Tomasella J. \& Hoodnett M. G. 1997. Estimating unsaturated hydraulic conductivity of Brazilian soils using soil water retention data. Soil Science, 162:703-712.

Tomasella J., Hoodnett M.G., Rossato L. 2000. Pedotransfer functions for the estimation of soil water retention in Brazilian soils. Soil Science Society of American Journal, 64:327-338.

Tomasella J., Pachepsky Y., Crestana S., Rawls W. 2003. Comparison of two techniques to develop pedotransfer functions for water retention. Soil Science Society of American Journal, 67:1085-1092.

Van den Berg M., Klamt E., Van Reeuwijk L.P., Sombroek W.G. 1997. Pedotransfer functions for the estimation of moisture retention characteristics of Ferralsols and related soils. Geoderma, 78:161-180.

Van Genuchten M.Th. 1980. A closed form equation for predicting the hydraulic conductivity of unsaturated soils. Soil Science Society of American Journal, 44:892-989.

Villagra M.M., Matsumoto O.M., Bacchi O.O.S., Moraes S.O., Libardi P.L., Reichardt K. 1988. Tensiometria e varibilidade espacial em Terra Roxa Estruturada. Revista Brasileira de Ciência do Solo, 12:205-210.

Williams J., Ross P.J., Bristow K.L. 1992. Prediction of the Campbell water retention function from texture, structure and organic matter In: van Genuchten, M.T.H., LEIJ, F.J., Lund, L.J. (eds.) Proceedings of the International Workshop on Indirect Methods for Estimating the Hydraulic Properties of Unsaturated Soils. Riverside, CA: University of California,p. 427-441.

Wösten J.H.M. 1997. Pedotransfer functions to evaluate soil quality. In: Gregorich, E.G., Carter, M.R. (eds.) Soil quality for crop production and ecosystem health. Developments in Soil Science, 25:221-245.

Wösten J.H.M., Pachepsky Y.A., Rawls W.J. 2001. Pedotransfer functions: bridging gap between available basic soil data and missing soil hydraulic characteristics. Journal of Hydrology, 251:123-150.

Wösten J.H.M. \& Van Genuchten M.Th. 1988. Using texture and other soil properties to predict the unsaturated soil hydraulic functions. Soil Science Society of American Journal, 52:1762-1770.

Arquivo digital disponível on-line no site www.sbgeo.org.br 